$12-31-2018$

\title{
A model of a large company's CSR and transformational community engagement strategy for SME development
}

Risa Bhinekawati

Sekolah Tinggi Manajemen IPMI, risa.bhinekawati@ipmi.ac.id

Follow this and additional works at: https://scholarhub.ui.ac.id/ajce

Part of the Social and Behavioral Sciences Commons

\section{Recommended Citation}

Bhinekawati, Risa (2018). A model of a large company's CSR and transformational community engagement strategy for SME development. ASEAN Journal of Community Engagement, 2(2). Available at: https://doi.org/10.7454/ajce.v2i2.130

Creative Commons License

(c) (i) ()

This work is licensed under a Creative Commons Attribution-Share Alike 4.0 License.

This Research Article is brought to you for free and open access by the Universitas Indonesia at ASEAN Journal of Community Engagement. It has been accepted for inclusion in ASEAN Journal of Community Engagement. 


\title{
A model of a large company's CSR and transformational community engagement for SME development
}

\author{
Risa Bhinekawati ${ }^{*}$ \\ a Sekolah Tinggi Manajemen IPMI \\ Received: September 13 $3^{\text {th }}, 2018$ || Revised: December $2^{\text {nd }}||$ Accepted: December 30 ${ }^{\text {th }}, 2018$
}

\begin{abstract}
This article presents a framework for a transformational community engagement strategy which has been implemented by Dharma Bhakti Astra Foundation (YDBA). It discusses the process under which a large company institutionalizes its corporate social responsibility (CSR) strategy, policy, and actions in developing small and medium enterprises (SMEs). Since 1980 the company has strengthened the capacity of 10,374 SMEs, which had created 65,855 jobs by 2017 . The paper shows the linkages between the concepts of CSR, transformational community engagement, social capital, and sustainability performance of a company. This study applies a qualitative case study to investigate why and how one of the largest public listed companies in Indonesia decided to play a role in developing SMEs as its CSR program; how transformational community engagement strategy is used in implementing the CSR program; and how the SME programs contribute to the company's triple bottom line through social capital development. The study finds that a large company can complement the government's roles in SME development, by sharing its knowledge and expertise, providing finance and market access, and also building social capital for SMEs. By doing so, the company enables SMEs to participate in economic activities and work collaboratively with the company in achieving sustainability performance for both the SME and the company. The conceptual framework developed from this study contributes to theory by clarifying the linkages between the concepts of CSR program, community engagement, and social capital. In practice, the framework can help business practitioners to design their CSR programs through community engagement. In reality, the ASEAN Business Advisory Council meeting in 2017 had considered YDBA's SME development program as a role model for other large companies operating in the region.
\end{abstract}

Keywords: Corporate social responsibility, Dharma Bhakti Astra Foundation, Social capital, Transformational community engagement, Indonesia.

\section{Introduction}

Until recently, there have been debates in literature about the role of companies in dealing with broad social issues such as poverty in developing countries. While the literatures on CSR, community engagement, social capital and corporate sustainability are interrelated, inter-linkages among the four concepts need to be clarified. Furthermore, the literature review in the field of CSR has shown a research gap and a need for research on the process under which CSR as an investment or input can contribute to the expected outcome, which is the triple bottom line of sustainability performance of a company

*Correspondence Author: risa.bhinekawati@ipmi.ac.id 
(Aguinis \& Glavas, 2012). Although research has been conducted on the 'business case' for CSR in attempt to show the linkage between CSR investment and corporate sustainability (Elkington, 1997; Hart, et al., 2003; Porter \& Kramer, 2006), the results have been inconclusive. Moreover, current studies by Bhinekawati $(2017,2018)$ and Bhinekawati and Asgha (2018) have clarified the nexus between CSR, social capital, sustainability performance and sustainable development, but do not elaborate on the concept of community engagement. Therefore, this research has two objectives. The first objective is to investigate the actual role of a large company in contributing to poverty eradication; while the second is to explore why and how the concepts of CSR, community engagement, social capital and corporate sustainability are interrelated and have evolve over time.

The community, which is broadly defined as "individuals sharing social well-being" (Bowen, Newenham-Kahindi, Herremans, 2010, p. 302), becomes one of key stakeholders of a company (Freeman, 2010). Hence, community engagement, which is a company's collaboration with the community to address social and economic issues (Scantlebury, 2003), can be seen as a broader company strategy for implementing its CSR (Bowen, 2007). Community engagement strategies can be categorized into "transactional, transitional, and transformational engagement" (Bowen, et al., 2010). Transformational engagement strategy, which is the most sustainable among the three categories, requires the company and the community to develop partnerships in joint problem solving, management of projects, decision-making, learning and sense-making (Bowen, et al., 2010, p. 307). As a result, such partnership will bring the intended benefit to both community and the company (Bowen, et al., 2010). However, research in transformational engagement strategy is lacking. A comprehensive literature review by Bowen et al. (2010) finds that there is still lack of clarity on the linkage between a company's motivation, investment, and benefit from transformational engagement. They suggest further research or case studies to clarify such linkages.

Based on the research gaps discussed above, this paper intends to answer research questions on why and how the concepts of CSR, transformational community engagement, and social capital interlink in the practice of a sustainable company. Based on the CSR journey of PT Astra International Tbk (Astra), one of Indonesia's largest public listed companies, this study finds that the company should play both private and public roles in implementing transformational community engagement strategy for its CSR 
programs. Astra has a corporate philosophy called "Catur Dharma" (four virtues) and a corporate aim "to prosper with the nation". Astra has conducted its public roles, which focus on SME development through the corporate foundation since 1980. The SME development program has strengthened the capacity of SMEs and other stakeholders that develop social capital for the company. Overall, the social capital generated through SME development program has contributed to the company's triple bottom line. Astra could be considered as one of Indonesia's indigenous companies that are sustainable, as it has evolved into Indonesia's reputable company with more than 200,000 employees by 2015 after it was established in 1957 as a small trading company (Astra International, 2015).

Subsequently, this study has therefore developed a theoretical model by comparing theoretical frameworks from literature with empirical evidence from Astra's experience. Indeed, the commitment of Astra in empowering SMEs has been seen as a good model by the ASEAN Business Advisory Committee as a practice that can be replicated in ASEAN Countries (YDBA, 2017). It is expected that the theoretical model generated from this study can contribute to the practice of companies aspiring to become sustainable in their operations in developing countries.

\subsection{CSR, Transformational Community Engagement, Social Capital and Corporate} Sustainability: A Theoretical Framework

A thorough review of past literature has revealed a possible linkage between CSR, community engagement, social capital, and corporate sustainability. CSR has been defined as "the economic, legal, ethical, and discretionary expectations that society has of organizations at a given point in time" (Caroll, 1979, p. 5000). Such social responsibilities that companies have towards meeting society's expectations should be translated into corporate strategy and actions (Carroll, 1979). The company has both intrinsic or ethical reasons and extrinsic or pragmatic justifications in conducting CSR programs. The intrinsic rationales drive the company to conduct CSR programs to solve universal issues such as poverty; while extrinsic rationales have given the company more tangible CSR benefits such as operations licensing and reputation building (Basu and Palazzo, 2008). Execution of intrinsic and extrinsic rationales can contribute to the triple bottom line of the company as well as to the improvement of community capabilities and living conditions (Basu \& Palazzo, 2008; Porter \& Kramer, 2006). 
With regard to the concept of community engagement has been seen as an important part of a company's overall social responsibility strategy in allocating resources to deal with social issues that are related to its competitive advantage (Bowen, 2007). The community engagement strategy has been seen as a strategy for enhancing partnership between a company and the community. Amnon (2004) found that companies are involving communities in their decision-making process and in policy making for their socio-economic engagement strategies with communities. Hence, sustainability and CSR goals of the company are the driving forces for companies to conduct CSR programs using the community engagement strategy. Further research by Bowen and colleagues (2010) suggested that the community engagement strategy can actually be considered as a component of a company's CSR programs and stakeholder relations while addressing the concerns of community groups. A comprehensive literature review by Bowen, et al. (2010) revealed that companies conduct transactional engagement using tactics such as charitable donations, employee volunteering, and information sessions, and using oneway communication from the company to the community with a motivation to "give back". Such an engagement would generate the limited nature of trust. While conducting transitional community engagement, the firm aims at building bridges and providing resources to communities, using stakeholder dialogue to address community needs. Transitional community engagement would generate an evolutionary nature of trust. On the contrary, when conducting transformational engagement strategy, the company aspires to change the society by conducting joint programs which allow the company to interact frequently hence build the relational nature of trust. Bowen, et al. (2010) further suggested that transformational engagement strategy is "the most proactive corporate engagement strategy" because it involves active participation and leadership roles from the community (pp. 305-306). It is suggested that transformational community engagement strategy would require long-term commitment that would benefit both the community and the company in a long-term (Bowen, et al. (2010).

In terms of social capital, a long-term company commitment of the company will allow long-term stakeholder relations in the process of managing company's CSR programs. Interactions among stakeholders towards achieving common CSR objectives have enhanced social capital though intense communications and collaborations between the community and the company. The relationships have allowed the company, as the driver of CSR programs, to act as the hub that integrates and facilitates different entities involved 
in the CSR activities. The company then becomes the focal point that develops social relations among people within the community (bonding) and between the community and the company (bridging). Strengthening of network ties through bonding and bridging are important elements of social capital development (Szreter \& Woolcock, 2004; Uphoff, 2000). When the bonding and bridging become stronger, trust and shared norms also increase among the people. Trust becomes the foundation for people in the network to share their resources towards achieving common objectives (Putnam, 1995, p. 67). A higher level of trust can only be achieved through long-term relations as it evolves over time (Coleman, 1990; Fukuyama, 1995). Hence, better developed social capital in the form of trust and social network would contribute to corporate sustainability. It is more likely that participants would co-create value with the company, in order to enhance sustainability performance for themselves as well as for the company.

Indeed, social capital can contribute to corporate sustainability, which is described as the ability of the company to achieve its economic, social, and environmental performance, which define the "triple bottom line", simultaneously (Elkington, 1997, p. 397; further, Hart, Milstein and Caggiano, 2003, p. 56). By achieving simultaneous economic, social, and environmental performance, a sustainable company actually contributes to sustainable development (Elkington, 1997, p. 297). Hence, a sustainable company preserves and improves the social and environmental conditions for future generations by achieving their financial performance (Elkington, 1997).

Therefore, a theoretical framework to show the linkage between corporate sustainability/CSR goals, transformational community engagement, social capital and corporate sustainability performance can be established from the above discussion, as depicted in Figure 1. 


$\begin{array}{cll}\underset{\text { Time 1 }}{\stackrel{\text { Event } 1}{1}} & \text { time } & \text { Timen } \\ \longrightarrow & \text { event } & \text { Event n }\end{array}$

\begin{tabular}{|c|c|c|c|}
\hline $\begin{array}{l}\text { Sustainabilityl } \\
\text { CSR Goal }\end{array}$ & $\begin{array}{c}\text { Transformational } \\
\text { Community Engagement }\end{array}$ & Social Capital & Sustainability Performance \\
\hline $\begin{array}{l}\text { - Aguinis and Glavas } \\
\text { (2012) } \\
\text { - Basu and Palazzo }\end{array}$ & $\begin{array}{l}\text { - Bowen, Newenham- } \\
\text { Kahindi, Herremans } \\
(2010))\end{array}$ & $\begin{array}{ll}\text { - } & \text { Bourdieu (1986) } \\
\text { - } & \text { Fukuyama (1995) } \\
\text { - } & \text { Putnam (1995) }\end{array}$ & $\begin{array}{l}\text { - Elkington, } 1997 \\
\text { - Hart, Milstein and } \\
\text { Caggiano (2003) }\end{array}$ \\
\hline $\begin{array}{ll} & (2008) \\
\text { - } & \text { Carroll (1979) } \\
\text { - Porter and Kramer } & \text { (2006) }\end{array}$ & $\begin{array}{l}\text { - } \text { Bowen }(2007 \\
\text { - Scantlebury } \\
\text { (2003) }\end{array}$ & $\begin{array}{ll}\text { - } & \text { Lin (1999) } \\
\text { - } & \text { Burt (1992) } \\
\text { - } & \text { Granovetter (2005) }\end{array}$ & - Schaltegger et al (2011) \\
\hline
\end{tabular}

Figure 1. Theoretical Framework for the Nexus between CSR, Transformational Community Engagement, Social Capital, and Corporate Sustainability Performance

In filling in the research gap and answering the research questions, the theoretical framework above should be compared with field evidence. After comparing the theoretical framework and the practical experience of a sustainable company, a theoretical model can be developed from this research. It is expected that the model can be replicated by companies aspiring to be sustainable in developing countries.

\section{Methods}

The data presented here are drawn from the author's PhD study on sustainable development, CSR and social capital at the Australian National University, which was conducted from 2010 to 2015. Data updates on community engagement programs were obtained by interviewing the Chairperson and Planning \& Development Manager of Dharma Bhakti Astra Foundation on March 02, 2018. In conducting the research, the author strictly followed the Australian National University (ANU)'s ethics procedure. The ethics clearance for this research from ANU and the consent from YDBA were obtained prior to the publication of this research. An exploratory qualitative case study approach (Baxter \& Jack, 2008; Stake, 2000; Yin, 2003; 2009) was applied in this research to investigate the process under which CSR, community engagement, social capital and triple bottom line evolve and are interlinked, within the practice of a large corporation, over a period of time. A case study was considered as an appropriate method for exploring why and how a process or a phenomenon evolves within a period of time (Stake, 2000; Yin, 2009). 
This study applied a single-embedded case study of PT Astra International Tbk, an indigenous Indonesian company that started as a small business in 1957 and developed into a large public listed company employing over 200,000 people in 2015 (Astra International, 2015). Since 1980 Astra managed its community engagement program through its corporate foundation that specializes in micro and SME empowerment, called the Dharma Bhakti Astra Foundation (YDBA). While conducting a qualitative case study (Meyer, 2001, p. 332), case selection is one of the most important decisions that a researcher has to make, because it is fundamental for building a theory from the case study (Eisenhardt, 1989, p. 537). Eisenhardt (1989) posits that the choice of cases should be done as a 'theoretical sampling' process, where cases are selectively chosen for replication and theory building (p. 537). Yin (2009) argues that a single case study design-holistic or embedded-is most suitable when testing or developing existing theory, when the case represents a 'unique case', or when the case is 'revelatory' (Yin, 2009 , p. 47). The case selection for qualitative research is different from quantitative, hypothesis-testing research, where the samples are randomly selected from the population (Eisenhardt, 1989, p. 537). Patton (1990) posits that 'purposeful sampling' can be applied where there are certain characteristics that qualify the case to be an exemplary case (pp. 169-186). According to Patton (1990), the characteristics that define a purposeful case include 'extreme or deviant case', such as outstanding successes or notable failures, crises, etc. (p. 169); 'intensity' of representing the strength of the phenomena to be studied (p. 171); 'stratified purposeful' for being able to illustrate particular interests and facilitate comparison (p. 174); 'critical case' that facilitates logical generalizations and maximum application of information to other cases (p. 174); 'criterion purposive' that the case meets the criteria for the sample under study (p. 176); 'theory-based or operational construct', representing manifestations of the theoretical constructs to be examined (p. 177). Based on theoretical or purposive sampling considerations, Astra was chosen as a case that is suitable for accomplishing the research objective (Eisenhardt \& Graebner, 2007, p. 27; Miles \& Huberman, 1994).

This study uses three sources of evidence, including semi-structured interviews, documents, and archival records. A total of 32 informants for the interview were selected from the beneficiaries of SME development program (13 owners of SMEs, 7 corporate management respondents), and 12 managers of a subsidiary company of Astra. The inclusion and exclusion criteria of interviewees' were based on the study design, which 
required multiple stakeholders to answer questions that allow triangulation with other sources of information (documents and archival records). A snowball technique (Miles \& Huberman, 1994) was used to identify relevant contacts for interview. For example, YDBA officials introduced the author to relevant people to be interviewed in other units of Astra. YDBA also invited the author to attend its person in charge meetings (coordination meetings of Astra's affiliated companies and their SMEs) with component subcontractors and service stations. During the meetings, the author obtained contacts for the interviews from Astra-affiliated companies and SMEs. The respondents were interviewed over 15 minutes to 2 hours, either individually or in groups. In addition to interviews, desk research was done to collect secondary data from sources such as published articles, company documents and archival records of SME development programs used for SME development over the past 30 years.

This study combined pattern matching and chronology techniques (Yin, 2009) to explore the links between CSR programs, community engagement strategies, social capital and sustainability performance of the company. The research also uses EndNote and Atlas.ti softwares for coding and data management. Comparisons were done between the theoretical framework and the empirical findings to draw conclusions (Eisenhardt, 1989; Eisenhardt \& Graebner, 2007). The sample questions used in the semi-structured interviews can be seen in Table 1.

Table 1. Illustration of interview questions

\begin{tabular}{|c|c|c|c|}
\hline $\begin{array}{l}\text { CSR } \\
\text { program }\end{array}$ & Research question & What to examine & $\begin{array}{l}\text { Sample interview questions to } \\
\text { company managers }\end{array}$ \\
\hline $\begin{array}{l}\text { Community } \\
\text { Engagement } \\
\text { to develop } \\
\text { Small } \\
\text { Medium } \\
\text { Enterprise } \\
\text { (SMEs) } \\
\text { Program }\end{array}$ & $\begin{array}{l}\text { 1. Why does Astra } \\
\text { decide to conduct } \\
\text { its CSR programs } \\
\text { through } \\
\text { Community } \\
\text { Engagement with } \\
\text { SMEs? } \\
\text { 2. How does Astra } \\
\text { formulate and } \\
\text { implement the } \\
\text { CSR program to } \\
\text { develop SMEs } \\
\text { through } \\
\text { community } \\
\text { engagement } \\
\text { strategy? }\end{array}$ & $\begin{array}{l}\text { The processes } \\
\text { under which the } \\
\text { corporate decisions } \\
\text { to undertake certain } \\
\text { CSR programs are } \\
\text { implemented by } \\
\text { internal and } \\
\text { external } \\
\text { stakeholders of the } \\
\text { company }\end{array}$ & $\begin{array}{l}\text { 1. Why do you conduct SMEs } \\
\text { Development Program? } \\
\text { 2. How does SMEs Development } \\
\text { Program evolve within your } \\
\text { corporation over time? } \\
\text { 3. How do you manage different lines of } \\
\text { business in your Small Medium } \\
\text { Enterprise (SMEs) Development } \\
\text { Program? } \\
\text { 4. How do you involve different levels of } \\
\text { management in ensuring successful } \\
\text { implementation of Small Medium } \\
\text { Enterprise (SMEs) Development } \\
\text { Program? } \\
\text { What are the resources you SMEs } \\
\text { Development Program? } \\
\text { How do you involve different external } \\
\text { stakeholders in building joint }\end{array}$ \\
\hline
\end{tabular}




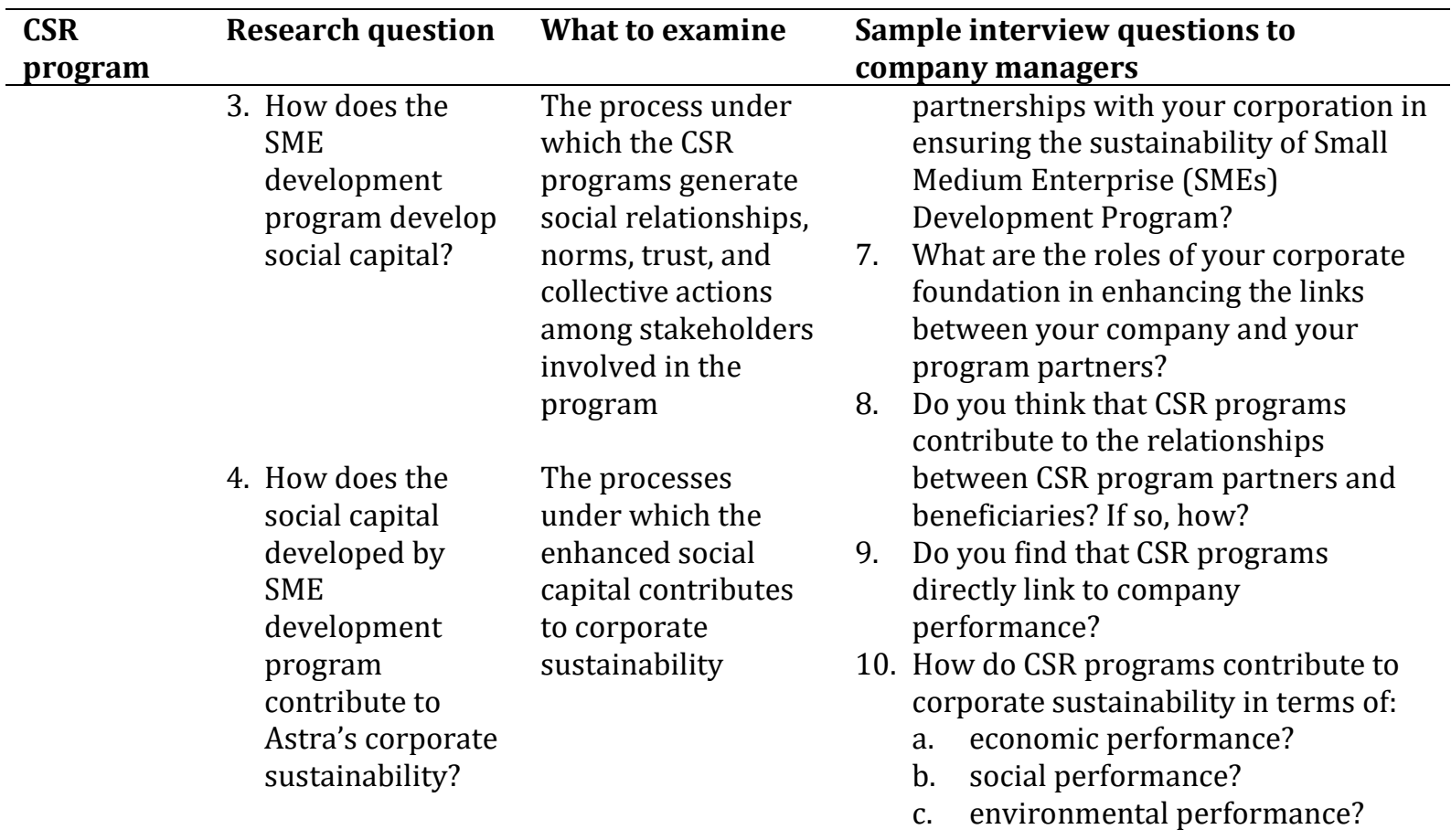

\section{Results and Discussion}

This study finds that the company has been very consistent with its aim "to prosper with the nation." To provide SMEs with the opportunity to participate in the corporate supply chain, the company has been empowering SMEs since 1980. Transformational community engagement has been done by YDBA through systematic steps in empowering SMEs to become self-reliant. Capability building for SMEs has been conducted by Dharma Bhakti Astra Foundation (YDBA), by giving SMEs access to knowledge, finance and market from Astra and Astra's connections. Over time, the corporate foundation has been able to develop an SME development ecosystem. As a result, social capital in the forms of social relations, such as networking among community members (bonding), and between community members and Astra (bridging) has improved. As the capability of SMEs improved, it became possible for them to engage in collective actions with Astra to achieve simultaneous performance in economic, social, and environmental growth for both SMEs and Astra, as depicted in Figure 2. 


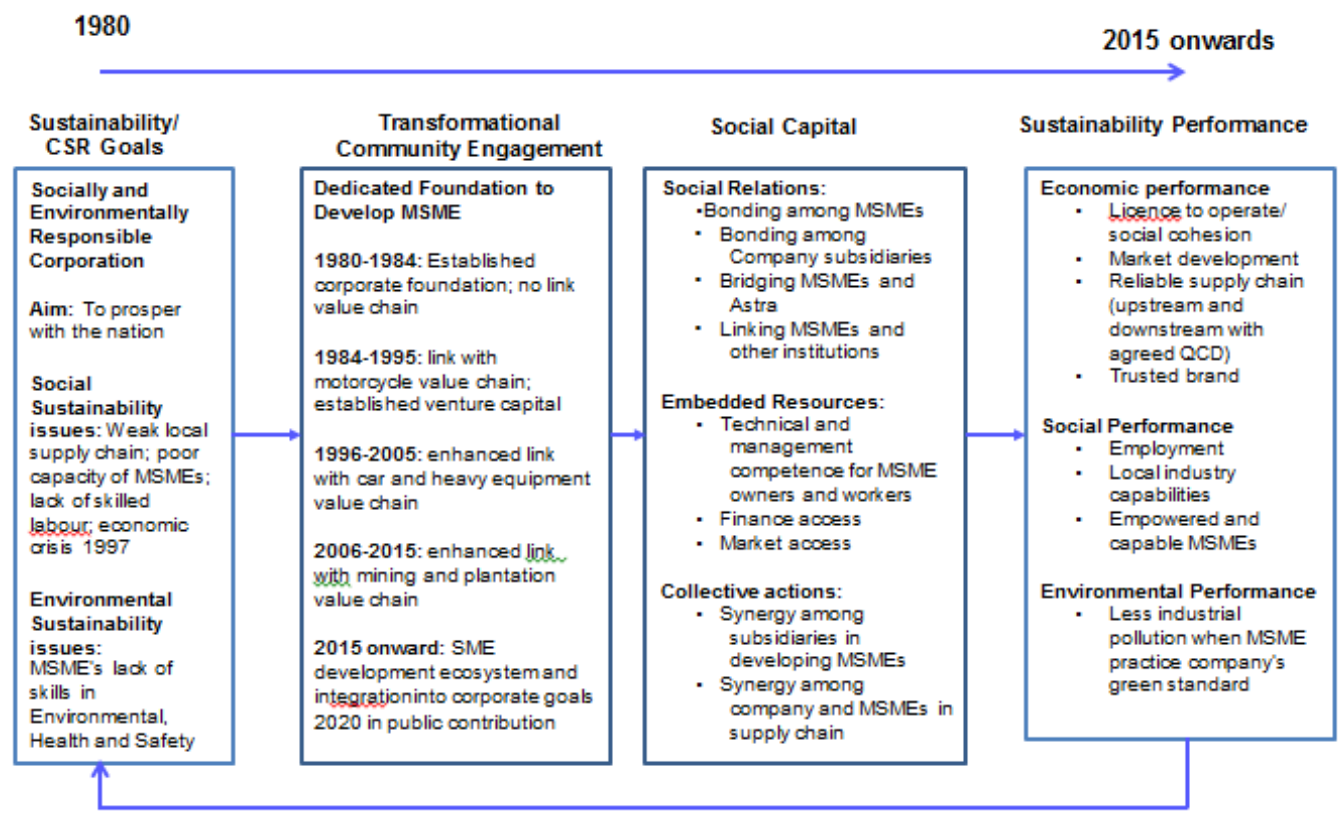

Figure 2. Transformational Community Engagement in PT Astra International's SME Development Program

\subsection{Sustainability/CSR goals as the Driving Force for Transformational Community}

\section{Engagement}

Experts suggest that companies should find environmental and social issues that are related to their corporate business. To do so, companies should have CSR and sustainability goals as the drivers or references for the company to implement its community engagement strategy (Basu \& Palazzo, 2008; Porter \& Kramer, 2006).

As a developing nation, Indonesia still faces universal challenges, such as scarcity of skilled labor (McKinsey Global Institute, 2012), deficiency in management and technical competence, lack of capital, lack of access to the market, and lack of business information, especially among SMEs (Tambunan, 2008, 2009). Overall, the country's main problem is poverty (UNDP, 2011) with severe environmental degradation issues (Edwards, 2005).

The evidence from Astra shows that the company has established its corporate aim, vision, and mission to address social and environmental issues facing the country in which it operates, which is Indonesia. When the corporate foundation (YDBA) was established, its vision and mission directly supported the intention of Astra to "prosper with the nation" and "to be an asset to the nation." YDBA supports Astra's corporate vision "to be a socially responsible corporation and to be environmentally friendly" by fulfilling its vision and mission to be "the best institution in the field of MSME development in 
Indonesia" with emphasis on strengthening SMEs and communities within and outside Astra's value chain (Astra International, 2015). As suggested by Bowen, et al. (2010), transformational community engagement happens when the company and the community engage in joint problem solving, joint project management, joint decisionmaking, learning, and sense-making. The process of transformational community engagement in SME development by YDBA has evolved since 1980. More recently, in 2015, YDBA established the "SME Development Ecosystem" where it conducted a bottom up process for communities wanting to work in partnership with YDBA. YDBA sets selection criteria for SME communities to check whether the products or services to be developed have the potential in terms of community leadership, community member's representation, technology transfer from Astra, market continuity, raw material availability, and alignment with government programs. Based on these criteria, SME community are selected and assisted by YDBA through linkages with "foster parents" within and outside Astra. For example, assuming a traditional blacksmith community producing knives in Klaten wants to improve their technology capabilities and product quality so that it can have better incomes. YDBA would connect them with Astra Agro Lestari which needs high quality egrek (knives to cut palm oil fruit). Currently the egrek is still being imported from Malaysia. YDBA then assists several members of the community to produce high quality egrek by giving intensive development on production management to ensure that their egreks would meet the quality standard required by Astra Agro. Once the selected community members can produce egrek consistently, they become the trainers for other members of community. After all members of the community are able to produce and sell their high quality egrek, YDBA will assist them to build cooperatives to facilitate their cash flow, raw materials, production equipment to enhance mutual trust and prosperity among the community members. Finally, after the cooperatives become an independent business unit, YDBA assists in reviewing its management process.

Until 2017, the numbers of SMEs assisted by YDBA has reached10,374 business units which have created 65,855 jobs (YDBA, 2017). Table 2 below the beneficiaries YDBA's SME development program. 
Table 2. SMEs and job creations by YDBA by 2017

\begin{tabular}{|c|c|c|c|}
\hline No. & SME classifications & SMEs & Jobs \\
\hline 1 & Manufacturers within the value chain of Astra & 308 & 30.100 \\
\hline 2 & Manufacturers outside the value chain of Astra & 103 & 1.689 \\
\hline 3 & Two-wheeler workshops-Honda partners & 60 & 180 \\
\hline 4 & Astra Honda Authorized Service Stations (AHASS) & 628 & 3.768 \\
\hline 5 & Two-wheelers - service stations developed by YDBA & 238 & 757 \\
\hline 6 & Four-wheelers - service stations developed by YDBA & 380 & 4.123 \\
\hline 7 & Members Business Development Agencies of YDBA & 4.238 & 18.474 \\
\hline 8 & Members of Micro Finance Institutions of YDBA & 4.255 & 5.097 \\
\hline \multirow[t]{2}{*}{9} & Handcrafters & 164 & 1.667 \\
\hline & Total MSMEs (cumulative) & 10.374 & 65.855 \\
\hline
\end{tabular}

The above empirical evidence from Astra's transformational community engagement through YDBA supports the assertions of Porter \& Kramer (2006) and Basu and Palazzo (2006), that company should develop CSR programs based on the social and environmental issues of the society, with which it interacts through its corporate sustainability and CSR goals.

\subsection{CSR implementation through Transformational Community Engagement Strategy}

The study finds that Astra has been implementing its CSR programs using a transformational community engagement strategy. This is in line with the views of Bowen (2007), Bowen, et al. (2010) and Scantlebury (2003). Astra CSR practice shows that transformational community engagement is a long-term process, having evolved via several phases of continuous adjustment. Table 3 summarizes four phases of the transformational community engagement strategy of Astra. 
Table 3. Evolution of Astra's Transformational Community Engagement Strategy

\begin{tabular}{|c|c|}
\hline Period & Transformational Community Engagement Strategy \\
\hline $1980-1984$ & $\begin{array}{l}\text { Initial Phase: YDBA provided machinery and revolving funds with no interest (pure } \\
\text { donations) }\end{array}$ \\
\hline $1984-2010$ & $\begin{array}{l}\text { Inclusion in corporate value chain } \\
\text { - } \quad \text { SME development to supply motorcycle components (1984 onward) } \\
\text { - } \quad \text { SME development for automotive components (1995 onward) } \\
\text { - } \quad \text { Broader SME development to improve income of communities surrounding } \\
\text { Astra plantations and mining ( } 2005 \text { onward) }\end{array}$ \\
\hline 1997-1998 & $\begin{array}{l}\text { Commitment to continue support to SMEs despite poor company conditions during } \\
\text { the economic crisis. }\end{array}$ \\
\hline 2010 onward & $\begin{array}{l}\text { YDBA programs continued to be integrated into Astra's aim to be the best company } \\
\text { in CSR and sustainable development }\end{array}$ \\
\hline
\end{tabular}

Source: within case analysis

Table 3 shows that the finding is in line with Bowen et al.'s (2010) assertion that the company's transformational community engagement strategy is far beyond corporate philantropy activities. The findings confirm that the alignment of corporate social investment with the identified environmental and social issues facing the country will allow the company to utilize its expertise and resources in improving the livelihood of the society (Davis, 1973).

\subsection{Transformational Community Engagement and Social Capital}

The case analysis of Astra's CSR program shows that transformational community engagement strategy conducted by YDBA has been able to develop social capital for Astra. It has been shown that the long-term commitment, shared resources, and capabilities among and between community members and of Astra has strengthened the bonding and bridged social capital for both Astra and its CSR beneficiaries, which can be illustrated from some of the statements from the interview as shown in Table 4. 
Table 4. Evidence of the increase in social capital through Community Engagement

Program

\begin{tabular}{|c|c|}
\hline Social Capital & atements by Respondents \\
\hline $\begin{array}{l}\text { Networks among } \\
\text { community } \\
\text { members } \\
\text { (Bonding) }\end{array}$ & $\begin{array}{l}\text { "So, we have many friends, we can share if for example we have problems with } \\
\text { motorcycle right. 'I never have this kind of motorcycle,' then I ask my friends who } \\
\text { are also members. Apparently one of them already got some experience on it." } \\
\text { (Taufik, 2011, lines 484-488) } \\
\text { "Actually, between AHASS workshops we are helping each other, we have to. So, } \\
\text { there are several cases for example, I don't have spare parts, and the shipment from } \\
\text { Astra has not arrived, I can actually borrow from other AHASS." (Aritonang, 2011, } \\
\text { lines 207-216) } \\
\text { "... the presence of YDBA, in my opinion, the SMEs sometime they feel the need for } \\
\text { information. The SMEs need information ... with the presence of YDBA, we always } \\
\text { have gathering with our SME friends, and we often get information although } \\
\text { sometimes only from informal conversations. Gradually we get the information... } \\
\text { Or sometimes we are invited to visit our SME friends. Well that ... according to } \\
\text { me, there are so many benefits, and also until this time, SME friends from YDBA } \\
\text { become close friends. And potentially, and in the future, will become business } \\
\text { friend as well." (Yunus, 2011, lines 214-218) }\end{array}$ \\
\hline $\begin{array}{l}\text { Networks } \\
\text { between } \\
\text { community } \\
\text { members and } \\
\text { Astra (Bridging) }\end{array}$ & $\begin{array}{l}\text { “... The forum is YDBA that unites that. That is the forum to unite, not to mention } \\
\text { Jabotabek [Jakarta and its surrounding areas] ... it spreads out to Tegal [MSME } \\
\text { cluster in Central Java]." (Sumardi, 2011, lines 217-223) } \\
\text { "Certainly ... the relationship happens because of coincidence, because we have } \\
\text { network like this. We are able to know the thing that we previously don't know, or } \\
\text { the information, "this one can do this, that one can do that, apparently that one can, } \\
\text { this one can," it is quick, "I need this," "Ooh ... that person can," something like } \\
\text { that." (Rakhman, 2011, lines 236-239) } \\
\text { "... but it is also possible for us together with YDBA, for example to visit the heavy } \\
\text { equipment companies, or the companies in the area of fabrication. There are also } \\
\text { accesses for friends who are giving information to me that, "Ooh ... there is a job } \\
\text { that is suitable for me," and sometimes I contact them as well." (Yunus, 2011, lines } \\
158-159 \text { ) }\end{array}$ \\
\hline
\end{tabular}

These findings support Bourdieu's assertion that social capital is developed through long-lasting relationships and mutual recognition (Bourdieu, 1986). Social capital can generate trust (Fukuyama, 1995) and also improves collective actions through mutual cooperation (Coleman, 1990). The collective actions will help the company to achieve its objectives (Uphoff, 2000).

The following Table 5 summarizes the social capital generated through the transformational engagement strategy used in Astra's CSR program. 
Table 5. Linkages between Transformational Community Engagement and Social Capital

\begin{tabular}{ll}
\hline Social Capital & YDBA for CSR program in MSME development \\
\hline Social relations & - Strengthened relationship among SMEs (bonding) \\
- Strengthened relationship among companies within Astra Group & (bonding) \\
- Strengthened relationship between SME community and Astra & (bridging) \\
- Strengthened relationship between MSMEs, Astra and other & organizations (bridging) \\
& - Transfer of knowledge (both management and technical) from \\
Embedded Resources & Astra to owners and workers of SMEs. \\
& Provision of access to finances for SMEs through venture capital \\
& and micro finance institutions. \\
- Provision of market access for SMEs who are able to meet Astra's & quality, cost and delivery standard. \\
- SMEs are able to produce components according to Astra's \\
standard. \\
- Companies within the Astra group share resources for SME \\
development. \\
- Other big companies participate in SME financing through YDBA. \\
\hline
\end{tabular}

Source: cross-case data analysis

Table 5 shows why and how the transformational community engagement strategy generates social capital. This finding supports Lin's(1999) assertion that the size of social capital equals to the size of resources and the network that can be utilized by people within the network (p. 37). In this case, Astra through YDBA has provided the participants of the CSR programs with a network and resources. Furthermore, Lin (1999) posits that the focal point of the network can serve as the hub that facilitates the bonding and bridging among and between stakeholders. YDBA as the hub has strengthened the bonding and bridging through various trainings, events, exhibitions, and visits that allow the owners of SMEs to meet frequently. Additionally, the sharing sessions among owners and employees of SMEs have enhanced trust and mutual cooperation among them, which enable the knowledge and resources to grow further (Coleman, 1990).

In terms of embedded resources, Astra has transfered three main resources to SMEs, including access to the market, management and technical skills, and finance.

Finally, the collective actions among SMEs and between SMEs and Astra have improved over time, because of the improvement of SME capabilities as well as the trust and social relations among them (Uphoff, 2000). In sum, the findings confirm that Astra CSR 
program's transformational community engagement strategy has created and delivered social capital.

\subsection{Social Capital and Corporate Sustainability}

The findings confirm the assertion by Hart, Milstein and Caggiano's (2003) that a company can contribute to sustainable development through its simultaneous performance in economic, social and environment or triple bottom line (p.56) conditions. Astra's economic, social, and environmental performance, which was achieved through social capital development from CSR programs and the transformational community engagement strategy in SME development are summarized in Table 6.

Table 6. Sustainability Performance of SME Development Program

\begin{tabular}{|c|c|}
\hline $\begin{array}{l}\text { Sustainability } \\
\text { Performance }\end{array}$ & CSR Program - MSME Development \\
\hline Economic Performance & $\begin{array}{l}\text { - Sustainable supply of components for automotive } \\
\text { - Reliable network of service stations for cars and motorcyles nationally. } \\
\text { - Business development for Astra products and services. As SMEs } \\
\text { become more prosperous, they become loyal customers for Astra. } \\
\text { - Good reputation as a sustainable company. } \\
\text { - Operating license. } \\
\text { - Consumer satisfaction and trusted brands because of nationwide after } \\
\text { - Eales services. }\end{array}$ \\
\hline Social Performance & $\begin{array}{l}\text { - Enhanced capability of workers and owners of SMEs. } \\
\text { - Enhanced capability of Indonesia's capability in producing automotive } \\
\text { components. } \\
\text { - Reduced unemployment as SMEs become capable employers. }\end{array}$ \\
\hline $\begin{array}{l}\text { Environmental } \\
\text { Performance }\end{array}$ & $\begin{array}{l}\text { Less industrial pollution as SMEs implement "Astra Green Company" } \\
\text { (AGC) standard. AGC puts specific indicators of pollution levels to be } \\
\text { managed by the company. }\end{array}$ \\
\hline
\end{tabular}

Source: cross-case data analysis

Table 6 shows the achievement of Astra's triple bottom line. In terms of economic performance, transformational community engagement strategy has transformed SMEs to become reliable manufacturers of automotive components that are able to ensure sustainability of supply for Astra's manufacturing needs. The CSR program has also enabled SMEs to provide after-services for Astra's cars and motorcycles. Furthermore, as financial conditions of SME owners and workers improve, they become customers of Astra's products and services. In other words, they become the new market for Astra. 
Being a good company within the community has enabled Astra to obtain and operating license. For example, during the 1997/1998 economic crisis, Astra premises were protected by the surrounding community from widespread riots. Moreover, the Astra's transformational community engagement strategy has brought consumer and employee satisfactions because they feel that they are dealing with a good company.

With regards to social performance, Astra's transformational community engagement strategy has contributed to solutions for unemployment, lack of competence, lack of market access, and lack of finance access of SMEs. By 2017, Astra's SME development program had empowered more than 10,000 SMEs overall, creating over 65,000 jobs (YDBA, 2017). Lastly, the SME development program of Astra has improved the SMEs waste handling capabilities, by applying Astra Green Company (AGC) standards in their operations.

Overall, this study expands the work of Bhinekawati (2017) and Bowen et al. (2010) by linking the concepts of CSR, community engagement, social capital and corporate sustainability performance. The transformational community engagement strategy model of CSR program generated from this empirical research is depicted in Figure 3.

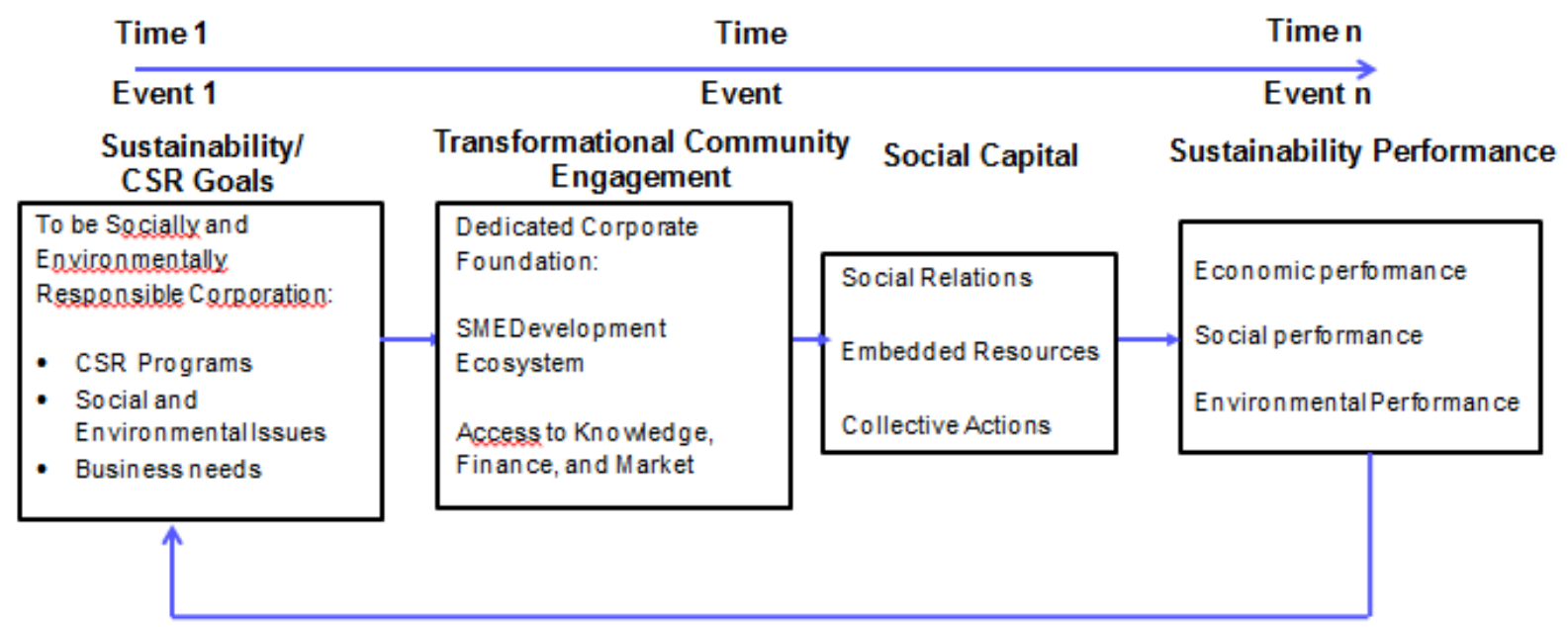

Figure 3. The Linkages between CSR, Transformational Community Engagement

Strategy, Social Capital and Corporate Sustainability Performance

The case of SME development by Astra has shown the process under which the triple bottom line of a company has been achieved by investing in a CSR program that was implemented using the transformational community engagement strategy. The community engagement strategy has generated social capital that contributed to 
simultaneous achievement of corporate sustainability performance for the company and the SMEs.

\section{Conclusion and Implications}

This study has met the two research objectives. First, the study has shown that the company plays both public and private roles in contributing to economic development and solving social issues such as poverty in the country. Secondly, the study has clarified the linkages between CSR programs, transformational community engagement strategy, social capital, and corporate sustainability performance which was lacking in the current literatures (Bhinekawati 2017; Bowen, 2007; Bowen, et al., 2010). The CSR and transformational community engagement model in Figure 3 shows that the achievement of sustainability performance starts with sustainability and CSR goals as the driving forces. When the leaders of a company care about achieving their sustainability performance, they will start looking at the strategic fit between environmental or social issues and their company needs (Basu \& Palazzo, 2008; Porter \& Kramer, 2006). Based on the strategic fit, they will decide on the best CSR programs to support the business while solving environmental and social issues. In the case of Astra, the company established a dedicated corporate foundation as the hub that connects the internal and external stakeholders in the program. The corporate foundation has become the focal point of an SME development ecosystem, which facilitates the implementation of transformational community engagement strategy. Intensive communications and interactions among internal and external stakeholders have built relationships, exchange of resources, and trust between Astra and SME community. The transformational community engagement strategy has generated social capital that contributes to simultaneous achievements of the company's triple bottom line and the company's sustainability performance.

For practical implications, it is expected that managers of companies operating in developing countries can replicate the developed theoretical model. Transformational community engagement becomes the strategy and process of conducting CSR programs, with social capital as the output; and corporate sustainability performance as the outcome of investment in CSR programs. Moreover, this paper will become one of the references of ASEAN businesses that aspire to contribute to social change through their CSR programs. Globally, this paper will enrich the company knowledge on how 
companies can achieve some goals of sustainable development, especially SME development and public private partnership.

Further research is needed due to research limitations. For instance, the theoretical model was developed based on field evidence from only one large company in Indonesia. While it is expected that the model can be replicated in other corporations operating in developing countries, further research is required to establish its applicability in other contexts.

\section{References}

Amnon, B. (2004). The Participation of Businesses in Community Decision Making. Business and Society, 44(2), 144-177.

Astra International. (2015). Sustainability Report 2015: Building Resilience Responsibly. Jakarta: Indonesia.

Basu, K. \& Palazzo, G. (2008). Corporate social responsibility: A process model of sensemaking. Academy of Management Review, 33(1), 122-136.

Baxter, P. \& Jack, S. (2008). Qualitative Case Study Methodology: Study Design and Implementation for Novice Researchers. The Qualitative Report, 13(4), 544-559.

Bhinekawati, R. (2017). Corporate Social Responsibility and Sustainable Development: Social Capital and Corporate Development in Emerging Economies. Oxon, UK: Routledge.

Bhinekawati, R. \& Asgha, B. (2018). Social Capital as Value Creation and Delivery of a Sustainable Business Model: A Case Study from Indonesia. In L. Moratis, F. Melissen ,S.O. Idowu (Eds.). Sustainable Business Models: Principles, Promise, and Practice. (pp. 305-327). USA: Springer International Publishing.

Bhinekawati, R. (2018). The linkages between CSR, social capital, and small enterprise development in a large company's supply chain. In D. Crowther, S. Shelfi, A. Moyen (Eds). The Goals of Sustainable Development: Responsiblity and Governance, (pp. 157178). Singapore: Springer Nature.

Bowen, F. (2007). Corporate social strategy: competing views from two theories of the firm. Journal of Business Ethics, 75(1), 97-113. 
Bowen, F., Newenham-Kahindi, A. \& Herremans, I (2010) When suits meet roots: the antecedents and consequences of community engagement strategy. Journal of Business Ethics, 95 (2), pp. 297-318.

Bourdieu, P. (1986). The forms of capital. In J. Richardson (Ed.), Handbook of theory and research for the sociology of education (pp. 241-258). New York: Greenwood Press.

Carroll, A. B. (1979). A three-dimensional conceptual model of corporate performance. The Academy of Management Review, 4(4), 497-505.

Coleman, J. (1990). Foundations of social theory. Cambridge, MA: Harvard University Press.

Davis, K. (1973). The case for and against business assumption of social responsibilities. Academy of Management Journal, 16, 312-322.

Edwards, M. (2005). Getting to the roots of the problems. Retrieved 10 March 2015, from http://wwf.panda.org/who we are/wwf offices/indonesia/environmental problem s indonesia/.

Eisenhardt, K. (1989). Building theories from case study research. Academy of Management Review, 14(4), 532-550.

Eisenhardt, K. \& Graebner, M. (2007). Theory building from cases: Opportunities and challenges. Academy of Management Journal, 50(1), 25-32.

Elkington, J. (1997). Cannibals with forks: The triple bottom line of 21st century business. Mankato, MN: Capstone.

Freeman. R. E. (2010). Strategic management: A stakeholder approach. New York: Cambridge University Press.

Fukuyama, F. (1995). Trust: The social virtues and the creation of prosperity. New York: Free Press.

Hart, S. L., Milstein, M. B. \& Caggiano, J. (2003). Creating sustainable value [and Executive Commentary]. The Academy of Management Executive, 17(2), 56-69.

Lin, N. (1999). Building a network theory of social capital. Connections, 22(1), 28-51.Porter, M. \& Kramer, M. (2006). Strategy and society: The link between competitive advantage and corporate social responsibility. Harvard Business Review (Reprint R0612D), 1-17.

London, T. \& Hart, S.L. (2004). Reinventing strategies for emerging markets: Beyond the transnational model. Journal of International Business Studies, 35(5), 350-70. 
McKinsey Global Institute. (2012). The archipelago economy: Unleashing Indonesia's potential. Washington, DC: McKinsey \& Company.

Miles, M. B. \& Huberman, A. M. (1994). Qualitative data analysis: An expanded sourcebook (2nd ed.). Thousand Oaks: Sage.

Patton, M. (1990). Qualitative Evaluation and Research Methods. Beverly Hill, CAS: Sage.

Putnam, R. D. (1995). Bowling alone: America's declining social capital. Journal of Democracy, 6(1), 65-78.

Scantlebury, M. (2003). The ownership structures of heritage toursim enterprise in Barbados and their institutional and community involvement. Waterloo: University of Waterloo.

Stake, R. E. (2000). Case studies. In N. K. Denzin \& Y. S. Lincoln (Eds.), Handbook of qualitative research (2nd ed.) (pp. 443-466). Thousand Oaks: Sage Publications, Inc.

Szreter, S. \& Woolcock, M. (2004). Health by association? Social capital, social theory, and the political economy of public health. International Journal of Epidemiology, 33, 650667.

Tambunan, T. (2008). SME development, economic growth, and government intervention in a developing country: The Indonesian story. Journal of International Entrepreneurship, 6, 147-167.

Tambunan, T. (2009). Promoting innovation in SMEs through transfer of technology. Tech Monitor (Jul-Aug 2009), 30-36.

UNDP (2014). Human Development Report 2014: Sustaining human progress, reducing vulnerabilities and building resilience. New York: United Nations Development Programme.

Uphoff, N. (Ed.). (2000). Understanding social capital: Learning from the analysis and experience of participation. Washington DC: World Bank.

YDBA (2017). YDBA Essentials. Jakarta: YDBA

YDBA (2017). Sharing YDBA di ASEAN Mentorship for Entrepreneurs Network. Retrieved 10 March 2018 from http://www.ydba.astra.co.id/mainnews/53/sharing-ydba-di-aseanmentorship-for-entrepreneurs-network

Yin, R. K. (2003). Applications of case study research (2nd ed.). Thousand Oaks, CA: Sage. Yin, R. K. (2009). Case study research: Design and methods (4th ed.). London: Sage. 